\title{
Feasibility Study for the Production of Bio-ethanol from Sugarcane in Mauritius
}

\author{
Ahmad Fahad Tayab ${ }^{1}$, Md Monower Zahid Khan ${ }^{2}$, S. M. Rafiul Islam ${ }^{3}$, Md Saleh Ebn Sharif ${ }^{2, *}$ \\ ${ }^{1}$ School of Aerospace, Mechanical and Manufacturing Engineering, RMIT University, Melbourne, Australia \\ ${ }^{2}$ Department of Electrical and Electronic Engineering, The University of Manchester, Manchester, UK \\ ${ }^{3}$ Department of Electrical \& Electronic Engineering, Bangladesh University of Engineering and Technology, Dhaka, Bangladesh
}

Email address:

saleh.electrical07@gmail.com(Md S. E. Sharif)

${ }^{*}$ Corresponding author

\section{To cite this article:}

Ahmad Fahad Tayab, Md Monower Zahid Khan, S. M. Rafiul Islam, Md Saleh Ebn Sharif. Feasibility Study for the Production of Bioethanol from Sugarcane in Mauritius.International Journal of Pharmacy and Chemistry. Vol. 5, No. 4, 2019, pp. 36-41.

doi: $10.11648 /$ j.ijpc.20190504.11

Received: August 14, 2019; Accepted: September 16, 2019; Published: October 5, 2019

\begin{abstract}
This paper summarizes a groundwork investigation of production of Bio-Ethanol from Sugarcane and analysis of its feasibility in terms of social, economic and environmental aspects. The main objective of this case study is to analyze the option available for ethanol production from sugarcane. As the disposal of sugar mill biomass (bagasse) is a major issue concern for environment, we also suggest the ways to efficiently use bagasse to produce steam and electricity - a sustainable solution of clean energy. Production of Bio-Ethanol is result of several steps of Extraction, Fermentation, Distillation \& Dehydration and we demonstrate a comparison of production of Bio-Ethanol from Bagasse and Molasses. In addition, preliminary analysis shows greater scope for more clean and green technology for the still grey areas.
\end{abstract}

Keywords: Bio Ethanol, Sustainable Energy Solution, Bio Fuel, Feasibility, Sugarcane

\section{Introduction}

The sugar industry has been the pillar of the Mauritian economy for decades. Sugarcane cultivation takes up $40 \%$ of the total island area as of 2010 [1]. The reduction of the price of sugar, reaching $36 \%$ by 2009 , under a sugar protocol has resulted in considerable loss of earnings for the sector and the national economy $[1,4,10]$.

In order to maintain the commercial viability and sustainability of the sugar sector, one particular group of sugarcane factories, namely Omnicane, started implementing a list of strategies. One main strategy was the setting up of a distillery complex for the production of ethanol from molasses. The distillery complex has several components, namely: Ethanol Distillery, a carbon dioxide bottling plant, a concentrated molasses solids (CMS) evaporation plant and CMS storage tanks, CMS fertilizer blending plant, associated infrastructure [2].

The distillery complex will be able to produce:

A. 15 million litres of anhydrous ethanol per annum from 65,000 tonnes of molasses, or up to 25 million of hydrous ethanol, from up to 90,000 tonnes of molasses

B. 25 tonnes per day of food grade carbon dioxide for local consumption in the beverage industry $(25 \%)$ and export to the region $(75 \%)$

C. 72,000 tonnes of liquid fertilizers for the planters' community.

From 1957 to 1981, there was a total generation of 31 GWh of electricity that was intermittent and produced from burning bagasse and using coal, followed by seasonal generation of $43 \mathrm{GWh}$ that started in 1982. As from 1985, a permanent generation of electricity was established where $104 \mathrm{GWh}$ was produced to $835 \mathrm{GWh}$ in 2005 and $1353 \mathrm{GWh}$ in 2008 [12-16].

The production of biofuel will provide for $10 \%$ blend (E10) with imported gasoline consumed by vehicles. This will provide an economic option for a decrease in imported fossil fuels for the local transport sector. Also, since the thermal and electrical energy for ethanol production comes from the power station that uses mainly bagasse during the crop season and coal during the inter-crop season, the distillery project is said 
to be sustainable. This is because part of the energy is derived from the system itself and the main raw material used to manufacture ethanol is molasses, which is a by-product of sugar processing. This will also produce bio fertilizer from Vinasse and beverage grade carbon dioxide[1, 12-15].

\section{Energy Related Services to Be Supplied}

\subsection{Energy Demand}

Figures below show the evolution of electricity generated from bagasse over the 1992-2012 period during which bagasse energy development had a high priority in the Mauritian sugar industry. The phasing out of intermittent electricity generation, as mentioned earlier, and shift towards continuous power is quite evident. Electricity generated from bagasse has increased considerably over the period. Furthermore, by the year 2012, the electricity generated from bagasse doubled from 2005, with amount of coal rising drastically.

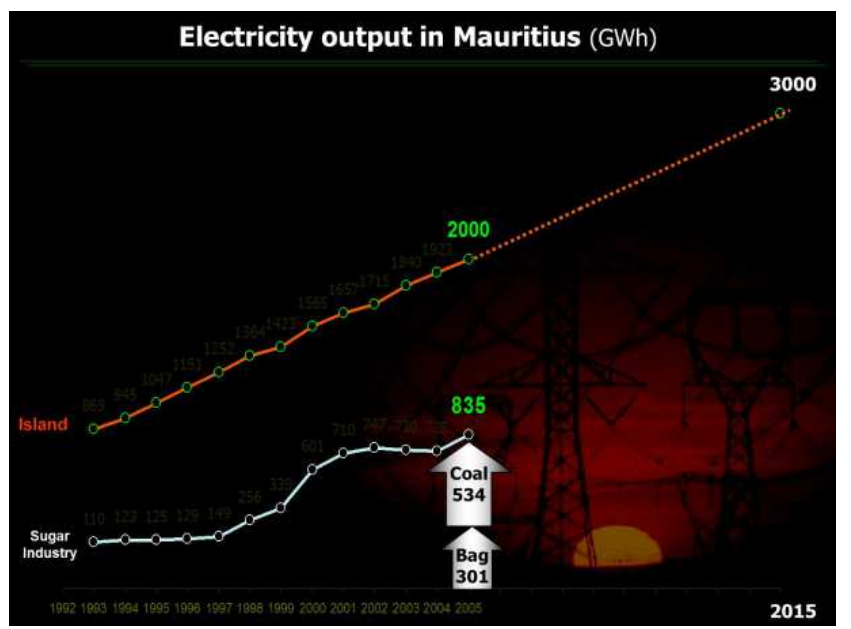

Figure 1. Electricity output in 2005.

In 2005 , bagasse and coal were already contributing to around $42 \%$ of total island electricity generation.

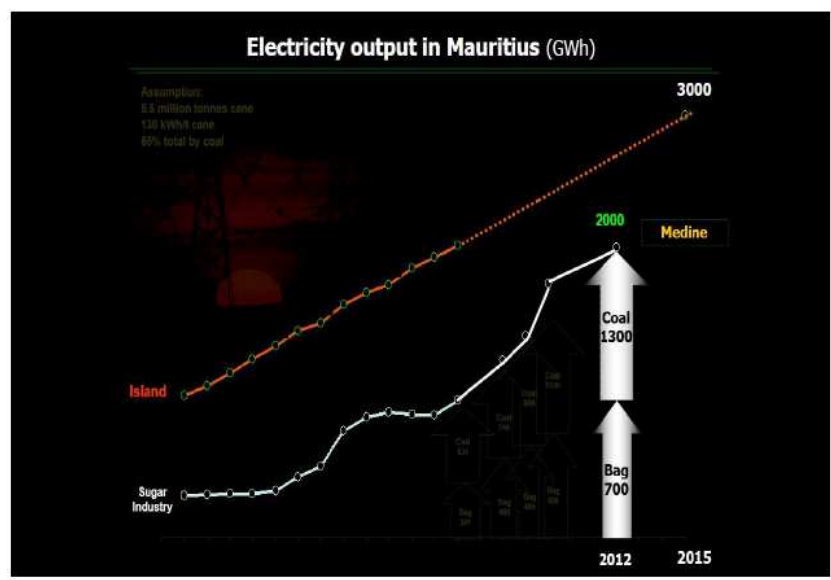

Figure 2. Electricity output in 2005
In 2012, coal and bagasse from the sugar industry were producing almost $2 / 3$ of the whole island electricity generation.

\subsection{Projected Electricity Export from Bagasse}

In spite of a reduction of land area for cane cultivation, electricity production is supposed to rise to $700 \mathrm{GWh}$ using current technologies and existing cane varieties [3].

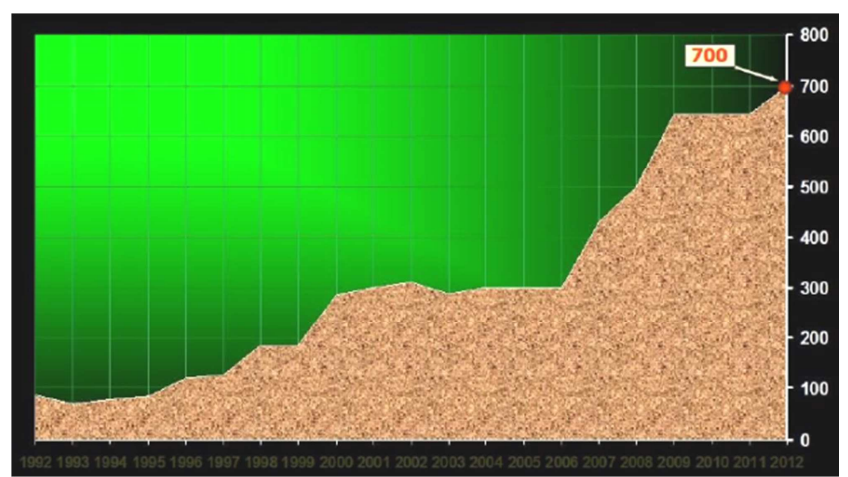

Figure 3. Projected electricity export from bagasse.

\subsection{Current Revenue from Sugarcane and By-products}

Sugar, electricity and ethanol are the most viable revenue from the sugarcane industry. Figure 7 shows that even though the quantity of sugarcane cultivation was reduced, there was still full output of sugar and increased quantity of ethanol and electricity.

The following were assumed for figure 4:

1 tonne sugar $=$ MUR 16,900

1 tonne cane@10\% IRSC = 100 kg=MUR 1690

Electricity@MUR 1.75 kWh=MUR 202

Ethanol@0.44 USD / litre=MUR 97

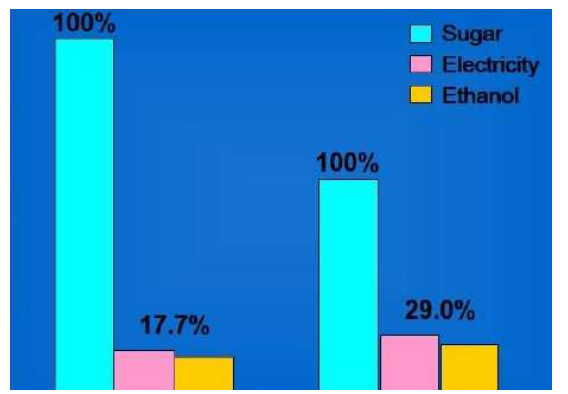

Figure 4. Current revenue from sugarcane.

\section{Bioethanol-the Sustainable Energy Solution}

Bioenergy includes solid, liquid, or gaseous fuels, as well as electric power or chemical products derived from organic matter, whether directly from plants or indirectly from plantderived industrial, commercial or urban wastes, or agricultural or forestry residues [7].

Liquid biofuels include pure plant oil, biodiesel and bioethanol. Biodiesel is based on esterification of plant oils. Ethanol is primarily derived from sugar, maize and other 
starchy crops. Global production of biofuels consists primarily of ethanol. Biodiesel comes second.

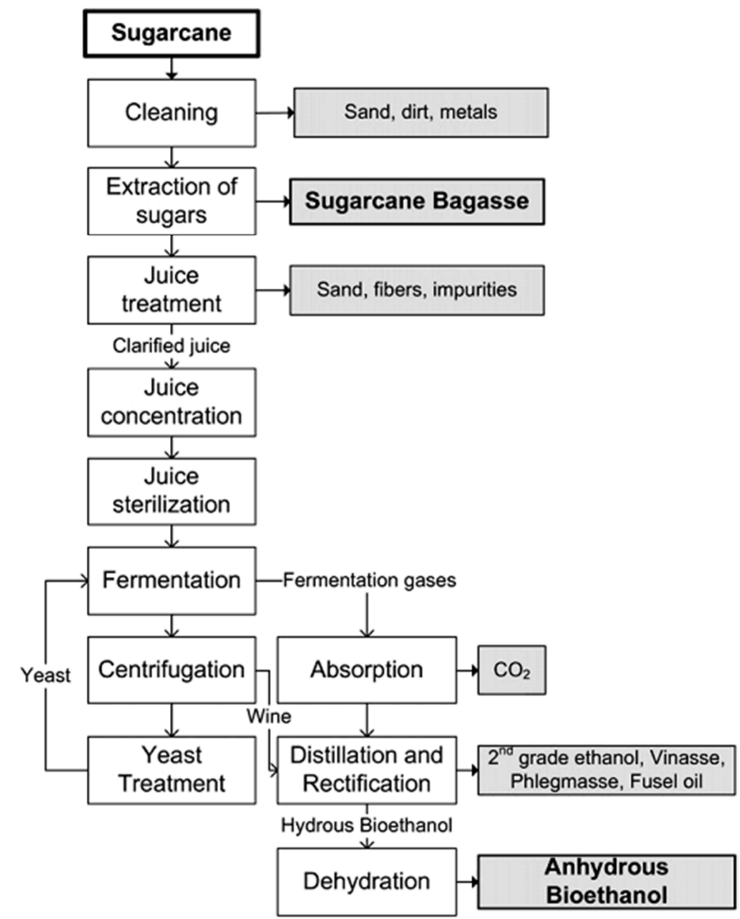

Figure 5. Block flow diagram of the conventional bioethanol production process from sugarcane.

\subsection{Production of Bioethanol}

The sugarcane plant is composed of leaves, stalk, tops and roots. It is the stalk that contains most of the sugars, being the main concern in industrial processing. After the sugarcane is harvested from the fields, either mechanically or manually, most of the leaves and tops, called sugarcane trash, are separated from the stalks and left on the fields. This increases soil protection and inhibits the growth of weed and other plant species. The composition of the sugarcane when it reached the factory is of mainly its stalks, containing water, fibre, sugars, impurities and dirt. Generally, sugarcane consists of sucrose, cellulose, hemicellulose, lignin, reducing sugars, minerals, impurities, water and dirt, where water and sucrose are of highest composition [6].

Conventional ethanol production consists of the following steps:

a) Cleaning of sugarcane and extraction of sugars

b) Juice treatment, concentration and sterilization

c) Fermentation

d) Distillation and dehydration.

A detailed description of the simulation of each of these steps is presented, and a block flow diagram is depicted in figure 8 .

\subsection{Production and Use of Liquid Biofuels}

Bioethanol is primarily produced by fermentation of sugar cane. The sugar cane is harvested and crushed, and soluble sugars are extracted by washing with water. Alternatively, bioethanol can be produced from wood or straw using acid hydrolysis and enzyme fermentation. This process is more complex and expensive.

\begin{tabular}{|c|c|c|c|c|}
\hline \multicolumn{5}{|c|}{ First generation (conventional) biofuels } \\
\hline Biofuel type & Specific names & Biomass feedstock & Production process & Uses \\
\hline Bioethanol & $\begin{array}{l}\text { Conventional } \\
\text { bioethanol }\end{array}$ & $\begin{array}{l}\text { Sugarcane, sweet } \\
\text { sorghum, sugar } \\
\text { beet, cassava, grains }\end{array}$ & $\begin{array}{l}\text { Hydrolysis and } \\
\text { fermentation }\end{array}$ & $\begin{array}{l}\text { Internal combustion } \\
\text { engine for } \\
\text { motorised transport }\end{array}$ \\
\hline \multicolumn{5}{|c|}{ Second generation biofuels } \\
\hline Bioethanol & $\begin{array}{l}\text { Cellulosic } \\
\text { bioethanol }\end{array}$ & $\begin{array}{l}\text { Lignocellulosic } \\
\text { material }\end{array}$ & $\begin{array}{l}\text { Advanced hydrolysis and } \\
\text { fermentation }\end{array}$ & \\
\hline
\end{tabular}

Figure 6. Production and use of bioethanol.

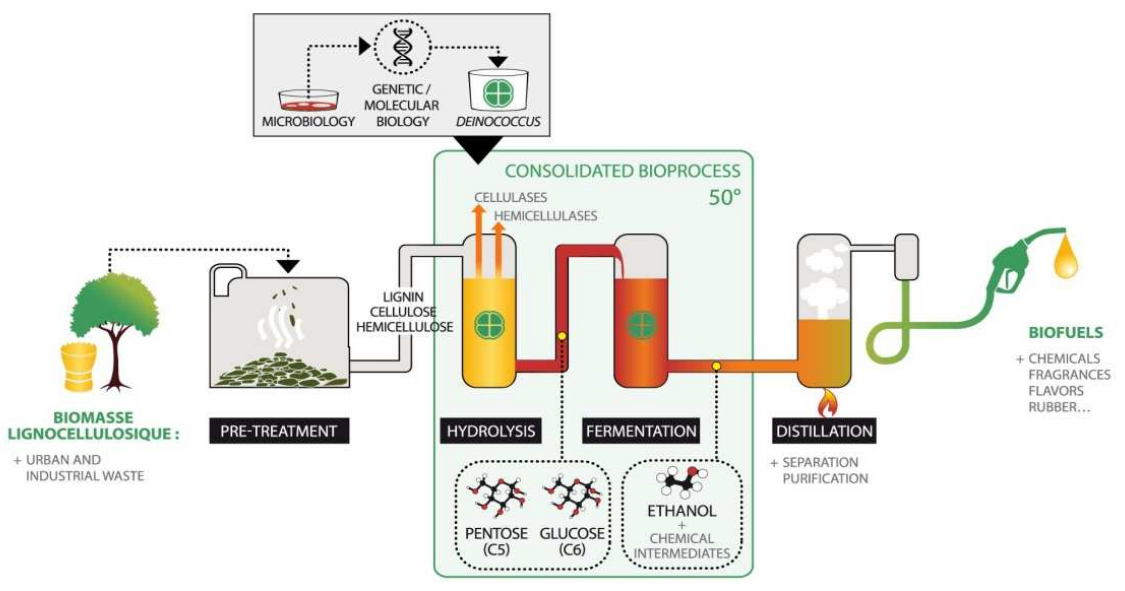

Figure 7. Second generation production of ethanol. 
In the current second-generation experiments, as shown in figure 7, after the bagasse is discarded after the first generation when the sugarcane broth is extracted to make ethanol, it enters a process of rupturing the cell walls to get the cellulose surrounded by hemicellulose and lignin, which is a polymer that has no sugar. A high pressure steam process is currently used for this rupturing, where the cell walls of the bagasse are relaxed, and components are separated by solvents, acids and enzymes. Force is used to get rid of everything around the cellulose. By starting hydrolysis in the field, sugarcane of second generation is readily available, hydrolysis is made easier, and there is no need to wash the bagasse that removes many sugars from the material [5].

\subsection{Ethanol from Bagasse}

There are three steps involved in the production of ethanol from bagasse and these are:

1. Lignin removal from bagasse

2. Convert hemicellulose and cellulose into simple sugars

3. Convert simple sugars into ethanol [3]

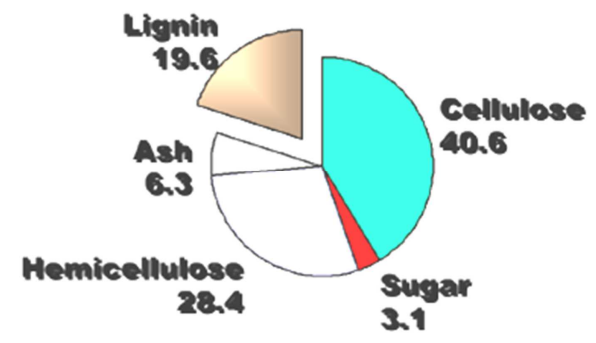

Figure 8. Composition of bagasse.

\subsection{Ethanol from Molasses}

Ethanol production involves steps as shown in figure 11. Fermentation is the enzymatic transformation of like sugar by micro-organisms, like yeast. The former process is followed by distillation, which is the separation process of constituents with different physical properties and boiling points [9].

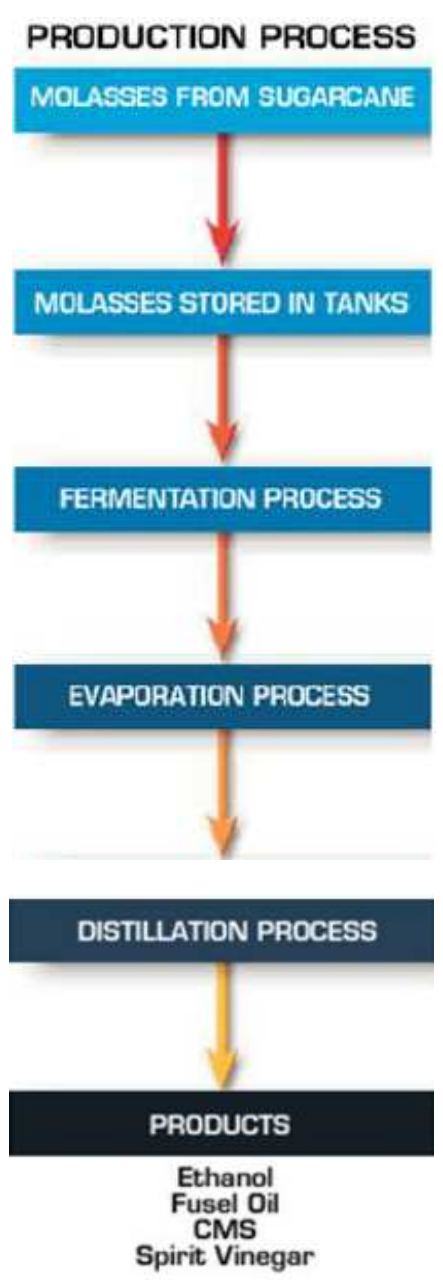

Figure 9. Molasses production process.

\subsection{Bagasse v/s Molasses}

Both ethanol production from bagasse and molasses have their own advantages and one is more beneficial than the other. Table 1 gives a very good comparison.

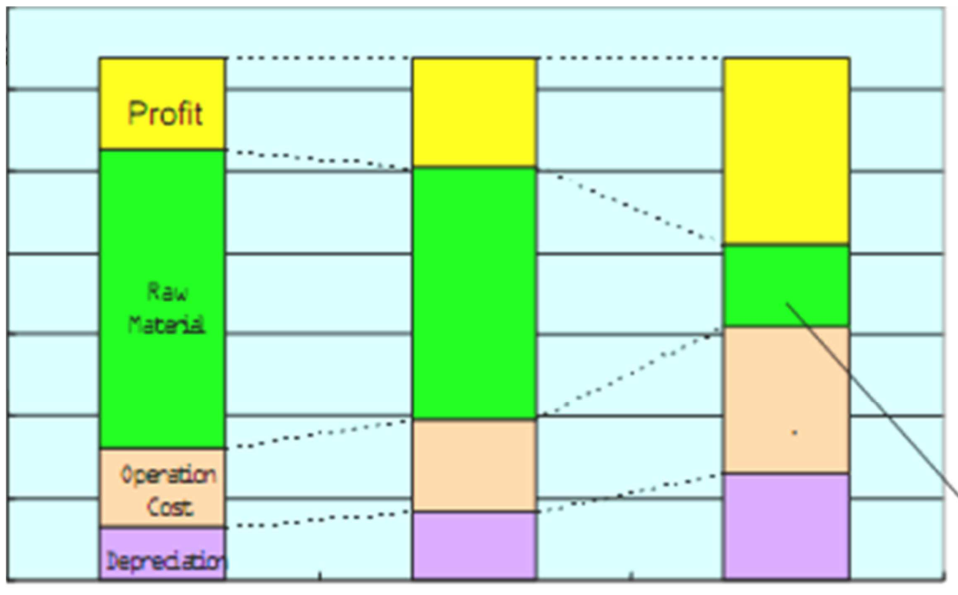

Only molasses Nolasses \& Bagasse Only Bagasse

Handling Cost of Bagasse

Figure 10. Ethanol production cost. 
Table1. Comparison of ethanol production processes.

\begin{tabular}{lll}
\hline Process & Merit & Demerit \\
\hline Molasses-to Ethanol Process & Plant cost is lower & Raw material cost fluctuates \\
Bagasse- to - ethanol Process & Raw material cost is stably low & Plant cost is higher \\
\hline
\end{tabular}

It is to be noted that even though it can be thought that producing ethanol from both bagasse and molasses at the same time would be better economically, figure 10 shows that the handling cost and profit are lower for bagasse, even though the operation cost might be higher.

G. Current situation

Even though bagasse would be the best product to produce ethanol, the operating Ethanol distillery in Mauritius has chosen molasses and is expected to produce:

a) 15 million litres of ethanol per annum from 65,000 tonnes of molasses

b) 25 tonnes per day of Food Grade carbon dioxide for local consumption in the beverage industry (25\%) and for export $(75 \%)$ c) 72,000 tonnes of liquid fertilizers for the planter's community [2]

There were a few concerns about the potential negative environmental impacts for the implementation of the distillery, which are:

a) Generation of vinasse, a by-product with a high organic concentration load

b) Reduced soil quality

c) Decreased ground water quality

d) Decreased surface water quality

e) Fire hazards due to the flammability of ethanol

Autrey, et al., 2006 presents, in table 1, a bio-refinery concept that the sugar industry is trying to implement, which included all processes involved [3].

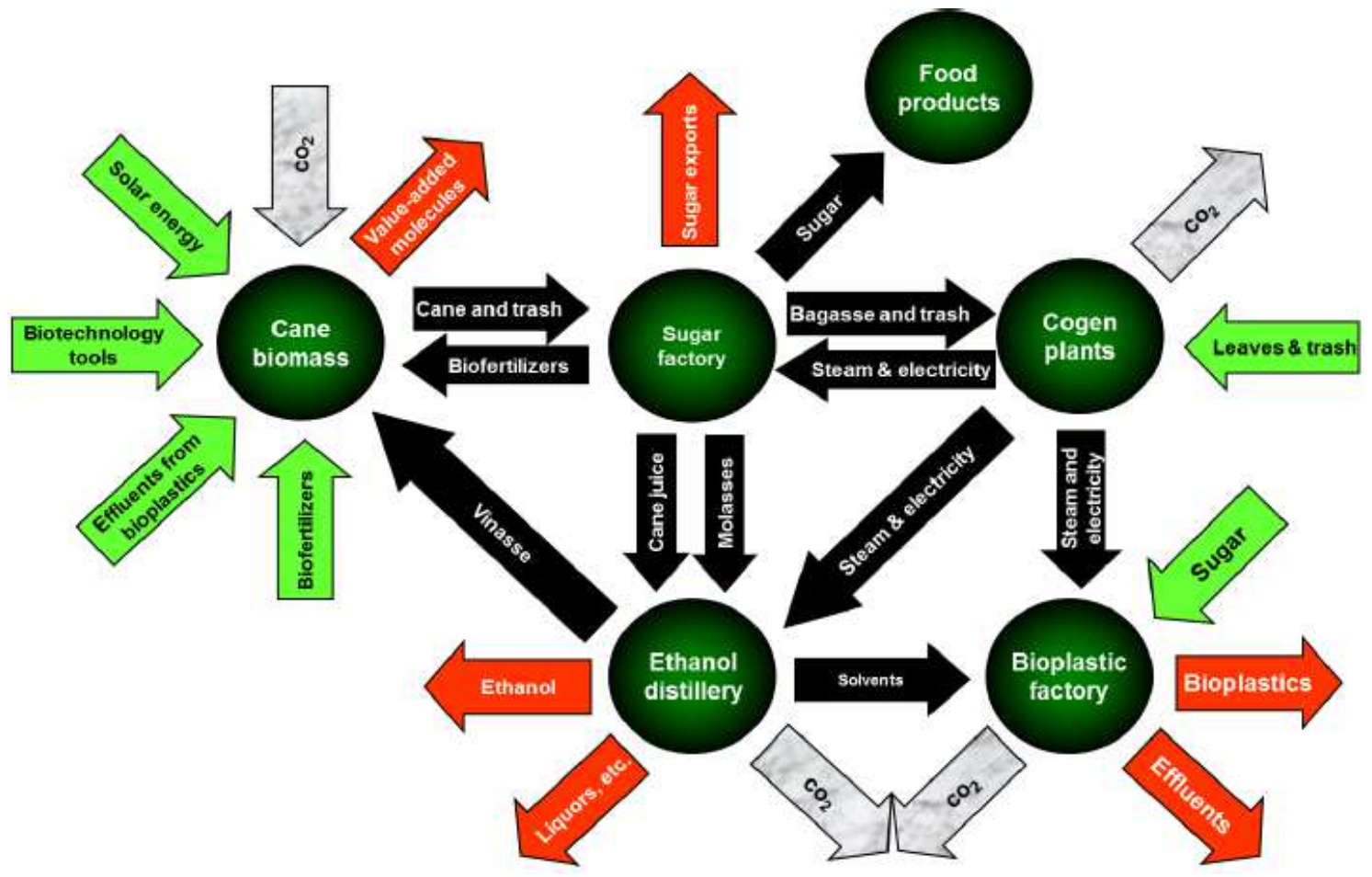

Figure 11. Bio-refinery concept.

\section{Triple Bottom Line Analysis}

\subsection{Economic and Social Development}

Substantial economic opportunities can arise for smallscale farmers and entrepreneurs as the biofuel industry grows, since production, transport, and processing of crops usually occur in rural areas. These rural communities can also obtain by-products of biofuels in terms of soap production or fertilizer as source of income. Small and largescale entrepreneurs have an important part to play in leading the creation of biofuels markets.

Bioethanol can be competitive if displacing more expensive fossil fuels. Government policies are required such as incentives for small scale producers, minimum price warranties, organization of farmers and cooperatives, information exchange and awareness raising, technical assistance and training, etc [7].

\subsection{Food Security and Energy}

Farmers can be provided with new income streams with sugarcane crops for biofuels. Also, non-edible crops can be grown and collected for biofuels applications. Many biofuels feedstock can be planted and grown on lands not used for cultivation. The main concern would be the competition of 
growing energy crops as compared to food crops. This can divert agricultural production away from food crops and this can increase prices. In South Africa, the average price for sugar increased by 12.6 percent in 2005 due to the rise in growing demand for ethanol in global markets. There might be also problems concerning growing crops for export, when there is an important need for energy access at home [7].

\subsection{Climate Change Mitigation}

There is no net increase in greenhouse gas emissions for the production of bioethanol. It can also lead to a reduction of emissions if used on a larger scale shifting fossil fuels. Nevertheless, biofuels for transportation release carbon dioxide into the atmosphere, where the carbon can then be used again for new plant growth. Emissions are considered to be carbon neutral when biofuels release carbon into the atmosphere, since the carbon is constantly recycled from the atmosphere as new energy crops are grown each season to make more biofuels.

The use of ethanol as fuel for the replacement of petrol in Mauritius can reduce the greenhouse gas emissions by around 540 tonnes, as 2,158 tonnes of emissions are produced from fuel combustion and $25 \%$ of it are from the transport sector [8].

\section{Conclusion}

Bioethanol will surely play a very important part in improving the lives of Mauritians. Biofuel technologies can offer modern energy services that leads to employment and income prospects, technological development, cleaner environment, energy security, and in general, an enhanced economic situation. The main objective of this case study is to analyze the option available for ethanol production from sugarcane. As the disposal of sugar mill biomass (bagasse) is a major issue concern for environment, we also suggest the ways to efficiently use bagasse to produce steam and electricity - a sustainable solution of clean energy. Bioethanol represents a fast and growing industry in Mauritius at the moment. Even though only one major company has invested in it, ethanol has a promising future for the local transport area.

\section{References}

[1] ARUP Sigma, 2011. Installation and operation of a distillery and concentrated molasses solids (CMS) fertilizer blending plant.
[2] Autrey, J. C., 2010. Omnicane - The Transition from Sugar to a Sugarcane Industrial Cluster, s.l.: s.n.

[3] Autrey, L., Kong Win Chang, K. \&Lau, A., 2006. A strategy towards enhanced bio-energy production from cane biomass.

[4] Cardona, C., Quintero, J. \& Paz, I., 2009. Production of bioethanol from sugarcane bagasse: Status and perspectives. Bioresource Technology.

[5] De Oliveira, M., 2012. FAPESP. [Online] Available at: http://revistapesquisa.fapesp.br/en/2012/10/19/betweensugars-and-genes/

[6] Dias, M. et al., 2009. Production of bioethanol and other biobased materials from sugarcane bagasse: Integration to conventional bioethanol production process. Chemical engineering research and design.

[7] Energy and Transport Branch, 2007. Small-Scale Production and Use of Liquid Biofuels in Sub-Saharan Africa: Perspectives for Sustainable Development. United Nations Department of Economic and Social Affairs.

[8] Environment Statistics, 2010. Environment Statistics. [Online] Available at: http://www.gov.mu/portal/goc/cso/ei920/toc.htm

[9] NCP Alcohols, 2012. NCP Alcohols. [Online] Available at: http://www.ncpalcohols.com/ethanol.asp

[10] Nair, Ramkumar\&Lennartsson, Patrik\&Taherzadeh, Mohammad. (2016). Bioethanol Production From Agricultural and Municipal Wastes. 10.1016/B978-0-444-63664-5.000083.

[11] Marandi, F. \& Ghomi, S. M. T. (2016). Time series forecasting and analysis of municipal solid waste generation in Tehran city. 14-18. 10.1109/INDUSENG.2016.7519343.

[12] Gogoi, Dr. Lakhimi. (2018). Solid Waste Disposal and Its Health Implications in Guwahati City.

[13] Rupf, Gloria \&Bahri, Parisa\& Boer, K. \& McHenry, Mark. (2018). THE ENERGY PRODUCTION POTENTIAL FROM ORGANIC SOLID WASTE IN SUB- SAHARAN AFRICA.

[14] Asadollahzadeh, Mohammadtaghi\&Ghasemian, Ali \&Saraeian, Ahmadreza\&Resalati, Hossein \&Lennartsson, Patrik\&Taherzadeh, Mohammad. (2017). Ethanol and Biomass Production from Spent Sulfite Liquor by Filamentous Fungi.

[15] Kheybari, Siamak, Mostafa Kazemi, and JafarRezaei. "Bioethanol facility location selection using best-worst method." Applied energy 242 (2019): 612-623.

[16] Wyman C. E., Cai C. M., Kumar R. (2019) Bioethanol from Lignocellulosic Biomass. In: Kaltschmitt M. (eds) Energy from Organic Materials (Biomass). Encyclopedia of Sustainability Science and Technology Series. Springer, New York, NY. 